7-31-2020

\title{
Developing an on-campus creative economy clinic to elevate the quality of existing community service program
}

\author{
Andri Zainal \\ Faculty of Economics, Universitas Negeri Medan, Indonesia, andrizainal@unimed.ac.id \\ T. Citra Nisa Farza \\ Faculty of Economics, Universitas Negeri Medan, Indonesia, citra.nisa@gmail.com
}

See next page for additional authors

Follow this and additional works at: https://scholarhub.ui.ac.id/ajce

Part of the Business Administration, Management, and Operations Commons, Business Analytics Commons, Entrepreneurial and Small Business Operations Commons, and the Organization Development Commons

\section{Recommended Citation}

Zainal, Andri; Farza, T. Citra Nisa; Harahap, Khairunnisa; and Dwi Putra, Pasca (2020). Developing an oncampus creative economy clinic to elevate the quality of existing community service program. ASEAN Journal of Community Engagement, 4(1).

Available at: https://doi.org/10.7454/ajce.v4i1.1080

Creative Commons License

\section{(c) (7) (2)}

This work is licensed under a Creative Commons Attribution-Share Alike 4.0 License.

This Research Article is brought to you for free and open access by the Universitas Indonesia at ASEAN Journal of Community Engagement. It has been accepted for inclusion in ASEAN Journal of Community Engagement. 


\title{
Developing an on-campus creative economy clinic to elevate the quality of existing community service program
}

\author{
Andri Zainala*, T. Citra Nissa Farzaa, Khairunnisa Harahapa, Pasca Dwi \\ Putra $^{a}$ \\ aFaculty of Economics, Universitas Negeri Medan, Indonesia
}

Received: March 26 $6^{\text {th }}, 2020||$ Revised: April $4^{\text {th }} \&$ June $2^{\text {nd }}, 2020$ || Accepted: July 29th 2020

\begin{abstract}
The ongoing community service program has not provided optimal and sustainable outcomes that can improve the creative economy sector as a partner, especially in the era of technological disruption. This study describes the importance of setting up a creative economy clinic at the university, which is based on the needs of upscaling local micro, small, and medium enterprises (MSMEs') performance. The discussions presented in the paper arise from a qualitative conceptual study using an instrumental case study approach, linking insights from theoretical perspectives and works across disciplines that concern the development of a creative economy clinic. The results of the discussion highlight the potential outcomes of establishing an on-campus creative economy clinic, ensuring the business sustainability of MSMEs in the era of disruptive technology. An initial assessment related to the needs of MSMEs is required as a strategic step in the development of the ecosystem of related creative economy clinics using each university's competitive advantage.
\end{abstract}

Keywords: community service program; MSMEs; universities; quadruple helix; creative economy clinic.

\section{Introduction}

The Fourth Industrial Revolution has led to the rapid development of technologies and computer-based applications and provided new challenges to developed and developing countries, including Indonesia. Many things related to human lifestyles are controlled by the latest technology, highlighting another significant element of the disruption era. To overcome these challenges, Indonesia should strengthen its potential, especially in the creative economy. As stated by the UNDP (2013), the creative economy is currently not considered a dynamic economic sector. Generally, the creative economy sector provides economic benefits for developing countries to grow and emerge with an inclusive and sustainable level of economic growth (Badan Ekonomi Kreatif, 2017).

The creative economy and related industries have become a dynamic economic driver in the modern world. Despite the different contextual issues within the creative economy

\footnotetext{
*Correspondence Author: andrizainal@unimed.ac.id
} 
among countries, cities, communities, and regions, the cultural and creative industries have initiated new business startups in many countries (Shafi, Sarker \& Junrong, 2019). The Indonesian Creative Agency envisages Indonesia joining an elite group in the world's creative industry. This motivation conforms to the government's plan to develop the nation to be one of the highest-income countries in the world by 2030 (Badan Ekonomi Kreatif, 2018).

Such an expectation seems feasible as the creative economy sector has a projected contribution to the national GDP (Gross Domestic Product) that gradually increases annually. In 2016, the creative economy's contribution to the national economy was 7.44 percent and was projected to increase steadily. In terms of value, the creative economy's GDP was expected to exceed 1,000 trillion Indonesian Rupiah in 2017 and close to 1,102 trillion Indonesian Rupiah in 2018. Data show that there has been an increase in the creative economy workforce: in 2016, 16.91 million people were working in the creative economy sector, which is higher than in 2015 (Badan Ekonomi Kreatif, 2018).

According to Wiagustini, Mustanda, Meydianawathi, and Abundanti (2017), micro, small, and medium enterprises (MSMEs) also play a significant role in the creative economy sector in many parts of the world. This sector relies on talent, skills, and creativity, which are essential for gaining prosperity through the optimization of intellectual creation. MSMEs are becoming leading players in the digital world today because of their rapid growth. The role of MSMEs is an essential driver of economic transformation across countries. The global outlook on the performance of the MSME sector is reflected in driving economic change, development, technological innovation, and job creation in both developing and developed countries (Eniola \& Ektebang, 2014; Nugraha, 2018).

The role of MSMEs is essential at the micro- and macro-levels in Indonesia. The success story of Indonesia's MSMEs is inseparable from the government's support of and function in the distribution of microfinance for MSMEs. Along with government encouragement, universities have an essential role in the development of the creative economy, especially in the MSME sector.

The role of universities in promoting the development of MSMEs has attracted much attention among researchers around the world. Several studies related to the role of universities in supporting the development of MSMEs have been conducted in several 
countries. For example, Darwish (2014) surveyed the role of universities in developing small and medium enterprises (SMEs) in Bahrain. Nicolaides (2011) analyzes the role of universities in South Africa, and Kasim (2011) conducted a similar study on how universities in Malaysia have formed an entrepreneurial agenda. Recently, Bomani, Fields, and Derera (2019) and Hunjet Kozina, and Kurečić (2015) examined the role of higher education institutions in the development of SMEs in Zimbabwe. Generally, the results of the studies indicate that tertiary institutions play a significant role in developing SMEs through training, technology transfer, business incubators, research, and research commercialization.

In the Indonesian context, to the best of the author's knowledge, there is only one study that is relevant to the role of Indonesian higher education institutions in the development of MSMEs in Indonesia. The review conducted by Dessy (2007) underlines the contribution of several large universities in Indonesia, such as Gadjah Mada University (UGM) and Bandung Institute of Technology (ITB) of the transfer of knowledge and technology to local SMEs. The knowledge and technology transfer mechanisms are manifested through business incubation programs that are managed explicitly by each university. But generally, in her conceptual study, Dessy (2007) highlighted the ineffective role of higher education institutions by both lecturers as individuals and universities as institutions in managing the sustainable development and empowerment program. Thus, the synergy between universities, industry, and government to advance SMEs in the context of the triple helix remains a mere slogan.

The Ministry of Education and Culture through the Directorate General of Research and Development has long provided a stimulus for community service programs to lecturers in Indonesia. However, its effectiveness is still questionable and is marked by the stagnant performance of MSMEs post the start of the community service program. Also, MSMEs in Indonesia still face obstacles in running and developing their businesses. They face increasingly complex problems, especially in the era of global markets. In many cases, multiple issues MSMEs face, such as access to finance, organization and human resources, business opportunities, bureaucracy and regulation, and bookkeeping can be easily managed. However, the resolution of these issues tends to be unsatisfactory as they are rarely complete and sustainable, particularly within MSME. 
One of the government's initiatives is to improve infrastructure to facilitate the in-andoutflows of goods produced by MSMEs. The existence of good infrastructure should also be supported by updating the MSMEs' capacity, especially in terms of using digital technology. By the end of 2018, only 5 percent of MSMEs in Indonesia were digital, and many more can still go digital. The lack of community interest in using existing digitalized media and the tendency of people accessing information from cellphones instead of computers have contributed to the ineffective performance of MSMEs in the adoption of technology in their business operations (Widiastuti \& Tjokropandojo, 2016).

Accordingly, universities in Indonesia should continue in their efforts to design various strategic work programs. These attempts are encouraged to support the growth and development of MSMEs, which are projected in the development and establishment of the creative economy clinical models. The existence of the creative economy clinic is sought to overcome the challenges and demands of conditions in the era of technological disruption and in welcoming the age of Society 5.0. At present, the trend toward the use of technology has narrowed to a human-centric paradigm (Fukuyama, 2018). Thus, a proper understanding and usage of digital technology by MSME actors will impact on strengthening the value chain of their businesses through innovation both in the virtual world and in reality, and fulfill the needs of the super-smart society segment.

To the best of the authors' knowledge, neither a conceptual paper nor a related empirical study has been found that investigates the importance of establishing a creative economy clinic in the university context. The lack of academic references provided in this area also justifies the ineffectiveness of current community research and service initiatives put forward by the university staff. The inefficiency arises from the nonholistic and temporary implications of research and service conducted in communities, which tend to be ceremonial. Activities and outcomes resulting in research and community service are probably undertaken as a regular academic procedure by lecturers and researchers at the universities. However, the Indonesian government has raised concerns about universities using research and community service outputs that will benefit stakeholders, including MSMEs.

Industry and the creative economy are the primary focus of business and government actors, given the enormous potential of these sectors, especially for MSMEs. In the national economy, MSMEs have an essential and strategic role. It is evident from the 
various empirical data that MSMEs are quite dominant in the Indonesian economy (Munandar, 2016). The success of the creative economy sector is inseparable from the role of government, entrepreneurs, academics, and the community that are bound together in the quadruple helix model introduced by Etzkowitz (2008). Besides, as a strategic facilitator for stakeholders in the development of the creative economy, lecturers and universities play an essential role in training, transfer of knowledge, and technology to MSMEs (Efi, 2014). Furthermore, the knowledge gained through training builds MSME technology capabilities, which can improve product quality and MSME services (Chipangura \& Kaseke, 2012).

\subsection{The role of University and Lecturers in the development of the creative economy}

The theory on the importance of organizational partnerships was put forward by Eisler and Montuori (2001) in 1998. An organizational partnership is needed as a strategy for organizational development faced with global uncertainty. Accordingly, an organization should collaborate closely with other organizations so that it can produce products at maximum quality and quantity (Herawati, 2011).

As explained in the introduction section, involving other stakeholders in a partnership setting is pivotal for (MSMEs) to cope with the dynamic of the existing MSME business environment. Related to this understanding, the government has positioned universities to play a central role in economic development (O'Malley, 2016). That universities have become engines for national prosperity is supported by Alexander and Evgeniy (2012), who state that "universities are agents of economic and technological development." Therefore, universities are increasingly expected to build and maintain relationships with the business sector, especially SMEs (Piterou \& Birch, 2014). They (SMEs) constitute more than 95 percent of the total registered businesses in the world and contribute to approximately 60 percent of jobs in the private sector and more than 50 percent of the world's GDP (D'Imperio, 2013).

A study by Efi (2014) reveals that universities in Nigeria play an essential role in training, transfer of knowledge, and technology to local SMEs. The knowledge gained through training in building the technological capabilities of SMEs has consequently improved the quality of products and services (Chipangura \& Kaseke, 2012). More importantly, universities make their research findings available on the Internet following 
the increasing number of online academic journals published by academics and researchers (Bacigalupo, Kampylis, Punie, \& Van den Brande, 2016; Bergmann, Geissler, Hundt, \& Grave, 2018; Boldureanu et al., 2020; Ismulyati and Ginting, 2018; Mei \& Symaco, 2020). Furthermore, the research findings provide essential sources and valuable information for SMEs to grow and develop their businesses (Bomani, Fields, \& Derera, 2019; Delfmann \& Koster, 2012). The partnership between universities and MSMEs through direct and sustainable assistance has a positive impact on the development of the creative economy sector. This study's findings agrees with Plechero (2009), highlighting that the relationship between universities and SMEs is developed mainly through direct and informal contact.

Some best practices can be regarded as examples related to the role of universities as a strategic facilitator for stakeholders in the development of the creative economy sector in the international context. The National University of Singapore successfully contributed to the dynamic economic shift toward knowledge-based economies in developing Singapore's creative industry sector. Other Asian countries have modeled this success story. Another success story is in South Korea. As reported in Yoon and Lee (2013) and Jung and Mah (2014), science-specialized universities and graduate school like Korea Advanced Institute of Science and Technology (KASIT) and Pohang University of Science and Technology (POSTECH) achieved outstanding achievements for their role in the growth of SMEs, research commercialization, the establishment of academic entrepreneurship education, and the establishment of sustainable networks with other universities and SMEs in the country.

The European Commission Bureau recorded that 15-20 percent of students participating in mini-company programs in schools within the European Union region are keen to start their own company (Wilson, 2012). The author further mentions the role of the knowledge-based economy in the United Kingdom as one of the factors for the prosperity of the British social economy. The partnership established by universities with business companies and the support of the British government has undoubtedly been a source of strength in the economic sector in the United Kingdom.

Not much different from the practice in several countries outlined in the previous paragraph, universities in Indonesia have still focused on the educational aspects, including consulting for structural and managerial improvements of business operations 
Andri Zainal, T. Citra Nissa Farza, Khairunnisa Harahap, Pasca Dwi Putra | ASEAN Journal of Community Engagement | Volume 4, Number 1, 2020

of creative economy sector actors (Doyle, 2016; Fahmi, McCann \& Koster, 2015; Gasparin \& Quinn, 2020; Kaymas, 2020; Kontrimienè \& Melnikas, 2017; Moore, 2014). Additionally, Fahmi, McCann and Koster (2015) also underline the accommodation of subjects relevant to the creative economy in entrepreneurship study programs at several universities in Bandung, Yogyakarta, and Surakarta as the object of their case studies.

1.2. The influence of the existence of a business incubator in The University on the development of creative economy

A business incubator is an institution that helps new entrepreneurs start their businesses to improve their prospects for development and endurance so that they can survive in a real business environment. According to Agustina (2011), a business incubator is a vehicle for transforming human resources that are not or are less creative and productive into those who are entrepreneurially motivated, creative, innovative, productive and cooperative, and who have competitive advantages, as well as vision and mission.

The concept of a business incubator in tertiary institutions has excellent potential to create new entrepreneurs through a business incubator program. The attempt is relevant to two significant tasks attached to the lecturers. They are to conduct research and community service activities consistent with their field of expertize. The actions of research and community service are expected to transform academic research findings into innovation so that a process of value creation can occur in societies. The outcomes are also likely to assist MSMEs in applying relevant technology to create and improve people's welfare (Campbell, 1989; Famiola \& Hartati, 2018; Li et al., 2020; Ndabeni, 2008; Obaji et al., 2015; Ogutu \& Kihonge, 2016; Pettersen, Aarstad, Høvig, \& Tobiassen 2015; Salem, 2014).

The existence of a business incubator in the higher education institution is instrumental in expanding existing businesses in the community and universities. The on-campus business incubator can further result in a university's profit center arising from the university's facilities and business units managed by the business incubator (Suwandi, 2007). However, these expectations seem not to perform correctly. The existence of business incubators in tertiary institutions does still not optimally accelerate the development of the creative economy. The reason is that the ecosystem supporting 
the role of the incubator has weaknesses in the incubator's governance system, such as (1) managers not being able to work full time; (2) the status of the business incubator autonomy and the time constraints of the incubator manager who is also a lecturer or researcher at the tertiary institution concerned; (3) coaching is conducted externally; (4) the administration includes but is not limited to an accompanying agreement or contract; and (5) operational funds are still minimal because they only rely on funding from tertiary institutions.

Accordingly, business incubators are only slightly incorporated into business incubator associations, and many business incubator managers do not have access to training or education on managing business incubators. The ratio of assistants and tenants is not proportional enough, and there is an insufficient frequency of intensive assistance and optimal quality of support. Weaknesses in management aspects and business incubator facilities are closely related to the structure of university business incubator financing (Agustina, 2011; Hasbullah et al., 2015; Suwandi, 2007).

The non-optimal role of managers in conducting their main tasks and functions within the incubator and the weak governance system results in the objectives of the business incubator not being achieved. The poor performance of the business incubator indicates that the incubator is treated as a supplementary formality in the accreditation instrument. It adds an extra burden on universities fulfilling the Tri Dharma role of tertiary institutions, which focuses on education, research, and community service within the framework of scientific development (Suwandi, 2007).

Further, the lack of an optimal business incubator in tertiary institutions is caused by the lack of a variety of products or business units within the business incubator. So, it is less able to meet market needs in the local, national, and international scope. Agustina (2011) highlights four relevant factors influencing the poor performance of the business incubator. They are (1) technology is still at a modest level; (2) the lack of an extensive network, including marketing; (3) the weak ability and business skills of the guided business actors; and (4) insufficient capital.

This study conceptually explores the need for establishing a creative economy clinic in tertiary institutions. More specifically, this discussion paper is generated from qualitative research toward actualizing an attempt to develop a creative economic clinic model at universities in Indonesia. The establishment of the creative economy model is expected 
Andri Zainal, T. Citra Nissa Farza, Khairunnisa Harahap, Pasca Dwi Putra | ASEAN Journal of Community Engagement | Volume 4, Number 1, 2020

to increase outcomes gained from the community service program and existing business incubators, sustainably. The next section discusses the qualitative research method, followed by a contextual exploration related to the initial mapping needed for the development of a creative economy clinic on campus. The author includes a qualitative study that specifically highlights the urgency of the existence of a creative economy clinic based on reviews related to the ineffectiveness of the role of business incubators in creating new startups. The last section contains the conclusions and implications of establishing a creative economy clinic for upgrading the community service program by increasing the mutual capacity and intensity of lecturers and MSMEs as partners in the creative economy clinic on campus.

\section{Methods}

The paper discusses the importance of establishing the creative economy model at a university from the authors' viewpoint. The basic idea of this paper stems from the phenomenon of the weak outcomes of existing community service programs conducted by lecturers as community service professionals that have real and sustainable impacts on MSMEs as implementing partners. It is also inspired by the modern medical treatment model operated in public health centers or clinics and specialty medical clinics, justifying the theoretical foundation for modeling the creative economy clinic on campus. The arguments are formed by the observation that focuses on a meaning-making as a qualitative scientific method (Krauss, 2005). This study emphasizes the attempt at developing logical and complete arguments, bridging Eisler and Montuori's (2001) theory of partnership of organizations and working across disciplines to expand the scope of thinking (Gilson \& Goldberg, 2015). Here, based on Gilson and Goldberg (2015), the link synthesizes multi-level insights that further underline the potential outcomes of the application of a creative economy clinical model in a university setting.

The approach of designing this conceptual paper pinpoints the theory synthesis type of paper proposed by Jaakkola (2020), highlighting a specific domain of discussion as the starting point, which, in this case, is the importance of establishing an on-campus creative economy clinic. This fundamental concept is further regarded as a variable equivalent being studied in the empirical research design. More specifically, to construct the discourse following steps developed by McGregor (2018). This research started from (a) 
investigating a specific issue, (b) compiling, generating, and evaluating relevant evidence, (c) establishing the importance of the focal topic that further creates a novelty of the paper, and (d) organizing sound, logic, and reasoning argumentation of the issue.

The analytical procedures used in this literature review are in-line with the instrumental case study approach (Stake, 1995). The intended case study includes a review of the syntheses published in books, journals, and mass media that are relevant to the specific issue emphasized in this paper, namely, the development of a creative economy clinic on campus. Stake (1995) further highlights the outcome of the exploration of various materials that are relevant to issues related to improving an existing condition. The state is to improve the quality of community service programs in the creative economy sector conducted by university lecturers. In particular, the requirement of setting up a creative economy clinic originates from the ongoing community research and service practices involving researchers from universities in Indonesia and local MSMEs as the partner.

\section{Result and Discussion}

3.1. Qualitative analysis of the development of the creative economy clinic model: Incorporating the quadruple helix approach

The quadruple helix concept builds on the triple helix concept by integrating the roles of academics, entrepreneurs, government, and society into creative activities and knowledge. Good collaboration among the four quadruple helix actors is needed so that each can play their role in encouraging the growth of the creative industry. Academics and companies provide the conditions required for an integrated innovation ecosystem. The government provides a regulatory framework and financial support for the definition and implementation of innovative strategies and policies. Civil society not only uses and applies knowledge, and demands innovation in the form of goods and services, but also becomes an active part as a user and operator in the innovation system. The additional helix includes civil society, comprising a media and culture-based society (Praswati, 2017).

Discussions on creativity and innovation performance in the creative industry with the support of quadruple helix are still unclear and still very limited. Currently, the Indonesian government is working to improve the quality of human resources in the 
creative industry to be more innovative, creative, and proactive so that they can engage in an innovation-based economy. As this research focuses on the scope of tertiary institutions, it is crucial to redefine the quadruple helix model in terms of developing the creative economy sector through the role of lecturers and tertiary institutions as researchers and community service.

Generally, academics, as researchers and community service professionals, have a role in providing new knowledge generated from research and development activities. Furthermore, the knowledge produced by academics will inform other actors. This information is used by creative businesses to develop and create innovation and creativity can increase value added to generate innovative products, where the interaction created between intellectuals and enterprises establishes a climate for the growth and development of innovation and creativity (Afonso, Monteiro, \& Thompson, 2012; Etzkowitz, 2008; Provenzano, Arnone, \& Seminara. 2016; Setyanti, 2017; Sofhani \& Nurrahma, 2017; McAdam, Miller, \& McAdam 2018; Jaelani, 2019). Correspondingly, the results of empirical studies also confirmed relevant studies conducted by Stanford University, Tsinghua University, Peking University, and universities in South Korea. The studies highlight the role of universities as science factories, providing findings of various sciences and technologies that are disseminated further to the public sector (Sofhani \& Nurrahma, 2017).

The proactive contribution of universities and lecturers shown in Sofhani and Nurrahma (2017) seems to be contrary to the current development of the creative industry in the City of Cimahi in Indonesia. The role of academics is minimal compared to other actors. The National Community Academy (AKN) is one of the universities in Cimahi City that is specifically engaged in fields that support the development of creative industries in the City of Cimahi, and it has not yet acted as a science factory. Currently, AKN's role focuses on developing human resources.

Apart from acting as researchers and community facilitators, lecturers and tertiary institutions also act as a medium connecting the synergy among MSMEs, the community, government, companies, and financial institutions. The objective is to create an ideal business ecosystem that supports the conditions required for the Fourth Industrial Revolution and Society 5.0 eras. As a facilitator that synergies other stakeholders, lecturers and universities must have digital-based competencies as essential skills. They 
are also required to have the competence to build networks to expand the knowledge and research directions that anticipate future constraints. More importantly, they must maintain cooperation among MSMEs, communities, governments, companies, and financial institutions to optimize the role in practice.

\subsection{The need for developing the on-campus creative economy clinic}

The increase in public awareness of the importance of high-quality services influences the increased demand for every public or private institution to provide optimal services in all aspects of life. In coping with the issue, universities in Indonesia intend to initiate a more effective community service strategy by setting up a creative economic clinic model to transfer skills to and empower MSMEs.

In the initial stages of developing the model, it was necessary to conduct a preliminary study identifying the needs of MSMEs in managing a sustainable business. Gronroos (1990) developed the Know Your Customers (KYC) strategy, which is considered one of the most meaningful service strategies, is used to provide excellent service by recognizing the needs and desires of users of the service. The KYC strategy in public services is used to verify the needs, interests, and aspirations of service users so that service delivery is responded to promptly. The KYC strategy provides excellent quality public services; hence, people are satisfied with the services offered (Rofida, 2018). Concerning the analysis of MSMEs' operations, we propose five key dimensions to be investigated further: (a) problems and obstacles faced by MSMEs; (b) type of support and services needed by MSMEs to overcome the problem; (c) the existence of support received by MSMEs; and (d) the importance of the present relevant business associations or facilitating supports benefit MSMEs' current business operations. Subsequent paragraphs present a brief discussion on a selected dimension of a demographic profile that was measured quantitatively.

This article identified the respondent's background information, which resulted in the profiles of both the MSME owner and the MSME. Indicators in the profile of MSME owners consist of general identity (full name, gender, age, last education, and address). The relevant descriptive statistic shows a dominant proportion of relatively young and productive micro- and small-sector-entrepreneurs in Medan City (25-29 years of age), 
75.5 percent from 207 local MSMEs followed by 17.8 percent and 6.7 percent of entrepreneurs aged 15-24 years old and over 60-years-old, respectively.

The profile of the business owner is important because some of the results of studies show that the poor quality of human resources can be seen by the low level of education of MSME owners. The frequency of MSME managers who have at least a diploma degree and above is considered minor (6.7 percent). In contrast, most MSME managers with senior high school leaving certificates or equivalent, and those with lower degrees amounted to 57.2 and 36.1 percent, respectively. The low level of education leads to MSME entrepreneurs being unable to grow their businesses and increase productivity (Nainggolan, 2016).

Gender is also predicted as one of the determining factors for the success of the business. The descriptive statistics concerning this indicator show that 24.15 percent of women are both the owner and manager of MSMEs, indicating that fewer women own and manage MSMEs than men (Kim \& Sherraden, 2014).

The use of other MSME profile indicators comprises (1) the current status of the business scope, (2) the type of MSME, (3) the tenure of the business, (4) the location of business operations, (5) business size in terms of revenue, and (6) the percentage of operating costs from income earned. These indicators can be a fruitful area for future studies. Some information related to these business profiles provides essential information on the ratio of business success to the scope of a business undertaken.

We opted to update the survey instrument for subsequent research by incorporating some indicators developed by the United Kingdom's Department of Business Innovations and Skill. The respective indicators explore business performance, problem needs, and factors that inhibit growth, to identify the needs of MSME owners for their business in the short and long term (Darwish, 2014). They are (a) the amount of the cost of doing business, (b) locations and places that suit business needs, (c) the quality of the workforce in terms of both numbers and qualifications of expertize, (d) ease and access to funding, (e) funding management, (f) development of innovation and leadership power, (g) integration or adaptation of new technologies, (h) the usage of e-commerce in business operations, (i) strategies for generating new customers and developing new target markets; (j) business planning, and (k) dealing with uncertain income acquisition. 
The results of the identification of MSME performance, especially those of the MSME needs, the description of business support and business consultations obtained, and the mechanism favored by MSME actors will assist the university in developing an efficient and effective creative economic clinic model that meets the needs of MSMEs.

The development of clinical models will provide recommendations on types of services that suit the needs of MSMEs. They will offer more individual services based on each business sector with different business settings such as culinary, computer and information technology, construction, education, entertainment, financial services, retailers, health care, and others. These types of services are supported by consultants with specific skill sets and competent stakeholders to strengthen the quadruple helix agenda. The settings will provide effective solutions by promoting proper training, facilitating finance and capital access, and applying digital technology in marketing and branding aspects.

Specifically, the requirement of establishing support by professional and competent consultants in their fields is crucial to developing trust in assistance and consultation services to the community. Excellent quality of service and facilities will not only prevent the failure of MSMEs but will also ensure that they can become independent after proper support is provided. For new business actors, it is critical to guide them in making business feasibility studies, finding the right location, developing business plans, and business proposals. These skills are essential for their businesses (Plechero, 2009; Wilson, 2012). Also, developing quality clinical services requires a culture of transparency, involvement, and openness between the involved parties. Each party should be involved in the design, delivery, and ongoing assessment of the support provided.

Lecturers, as researchers and community service professionals, have done much work and have applied the results of the research to the community on a one-to-one approach. This method highlights the one-shot facilitator function of a lecturer to the owner of MSME as the partner of conducted community service program. In many cases, the resolution of MSME problems can be resolved but not holistically and continuously due to certain circumstances and limitations. So, it is crucial to redefine the quadruple helix model in terms of developing the creative economy sector through the role of lecturers and tertiary institutions as researchers and community service providers as well as 
facilitating institutions in the synergy scheme of MSMEs-community or communitiesgovernment-companies-financial institutions related to the creative business ecosystems relevant to the conditions necessitated by the Fourth Industrial Revolution and Society 5.0.

One example is what has been done by the Central Bank of Indonesia (BI) through the Leading Entrepreneur Program, widely known as Program Wirausaha Unggulan Bank Indonesia (WUBI). This program provides an arena for MSMEs to be assisted in all BI operational areas to maintain local and national fiscal and monetary stability by keeping the business performance of MSMEs on track. The significant points from WUBI are the continuous and comprehensive mentorship programs involving a series of activities: Bootcamp, regular coaching, monitoring, and evaluation of the on-site business location of the participants, benchmarking, and focus group discussion of the taught learning material conducted within six months. Another highlight is the establishment of an entrepreneur community that will lead a subsequent social community service in helping other business starters from inside and outside the BI circumstances.

The establishment of a creative economy clinic is crucial as it is expected to improve the community service program through a stimulus from the directorate of research and community service and internal university funding. The existence of a creative economy clinic in higher education answers criticism from Saad and Zawdie (2011). They highlight the tendency of realization of community service programs in the MSME segment engaged in the non-high-technology and non-capital sectors and the lack of communication and networks that bridge MSMEs, the government, and industry. So, the quadruple helix context has not yet been applied adequately as a result of the low intervention by tertiary institutions.

The establishment of a creative economy clinic will offer increased space for the lecturer's team to provide additional assistance to the actors in the creative economy sector as partners. A more intense engagement between lecturers and MSME actors will further strengthen the value creation of businesses resulting from the more flexible time arrangements and aligning the lecturers' current teaching and other academic activities. Increased substantial value creation of the managed company will create additional confidence and business independence by the creative economy actors. Consequently, 
they will be more empowered to gain access to the investor or industry for their business development with or without university intervention.

3.3. The on-campus creative economy clinic: An alternative agenda for upgrading the quality of Lecturers' community service or engagements

As explained earlier, lecturers in Indonesia play a role as community service professionals in fulfillment of the Tri Dharma of higher education. This role has been ongoing ever since the Tri Dharma of higher education was embedded in the vision and mission of national higher education. Notably, the dynamic of output resulting from the start of community service programs by lecturers in various universities in Indonesia has significantly evolved. A notable form of development is the shift in the format of the outcomes that were initially based on activities or completed work. The current setup has now turned into a mechanism containing more regular events and product innovations. It is mandated that this format is to be generated from the applied research conducted by the lecturers' team. The implication is that this applied research is generally performed under the initiation and adoption of appropriate technology-based production machinery and processing by their implementing partners (so-called as Mitra in the local context).

In this current era of higher education management, the demand to produce innovative work has raised critical concerns for the university. It has also been transformed into one of the essential instruments of universities' key performance indicators (KPI), marking the level of success of universities managing their related academic and nonacademic activities in national, regional, and global contexts. One of the KPIs is the establishment of a business incubator, and its contribution, reflecting the implementation of the quadruple helix model among universities, industries, and potential business actors in the case of startup companies.

The existence of business incubators in higher education institutions has brought a particular contribution to the growth and development of business for the majority partners involved in the UMKM sector, especially for those who use the latest technology in the production and operational processes needed to meet the criteria for a startup. However, in its development, the existence and function of the business incubator tend not to have a significant effect on accelerating the development of startups that 
characterize innovative and creative businesses on an ongoing basis. If we further look into the top 20 or 30 most prominent startups (both in terms of revenue and valuation) of approximately 1307 startups in Indonesia (Pramudita, 2019), none of the top 30 technology-based startup enterprises started in an existing business incubator program managed by universities in Indonesia.

Consequently, the existence of a business incubator that is also set as an essential agenda in the national strategic development programs does not reflect the actual value creation. In other words, the effectiveness of the program and its efficiency in budget spending is questionable. Khurana (2017) criticizes the incompatibility of programs developed by business incubator managers who lack competent mentors as a fundamental weakness. The mentorship-related activities are critical in the management of business incubators. An ineffective mentorship hinders the founders' efforts to increase their business value creation. It further contributes to the dysfunctional business ecosystems. Therefore, these formalities also provide for and affect the effectiveness of the operational business incubator in producing startups that have adequate performance in terms of revenue and business creation.

Furthermore, Khurana (2017) recommends several strategic attempts to increase the effectiveness and efficiency of managing a business scheme for startup companies based on partnerships with universities. The steps in managing a startup business scheme include the creative economy sector. The first step eliminates the classroom learningbased approach. The following step contains proactive participation, including the involvement of mentors, who have different academic and professional qualifications in dealing with partner problems. The last step establishes a community of entrepreneurs to facilitate broader business discussions and to help each other through a collaborative business synergy on an ongoing basis.

More specifically, the proposed methods are included in the establishment of a creative economics clinic in higher education institutions. The establishment of oncampus creative economics clinics is expected to redefine the model and implementation of community service programs that do not support the sustainability of both the MSME and the lecturer. The current mechanism must be reformed to underline the longevity that creates value for MSMEs engaged in the creative economy sector. 
The specific scheme emphasized by Khurana (2017) has promising outcomes for the adoption of the model that establishes creative economics clinics. It highlights the more intense approach of a combination of competencies of the professional community service and the resources available on the campus to strengthen the innovation and entrepreneurial creativity of partners. Additionally, this more intense approach will provide more effective support for MSMEs to upgrade their capabilities to meet the criteria for technology-based startups.

The modification that enhances the current implementation of community service programs that centralizes the creative economy clinic on campus has advantages for lecturers. One of the significant benefits is the efficiency of their mobility in conducting the Tri Dharma of higher education integrated on campus-site. Consequently, the time efficiency may no longer be an issue. Nevertheless, it also provides access for mobilizing students to conduct entrepreneurial project-based learning practices in their field of science. Further, the students will also develop a new foundation of creativity and innovation for their future projects.

\section{Conclusion}

This paper provides the discourse on the establishment of on-campus creative economy clinics as a medium of acceleration and optimization of the role of universities in the development of the creative economy sector, which is currently dominated by MSMEs. Accordingly, the founding of a creative economy clinic on campus can be an alternative to improving the higher level of quality of community service programs through more intense interaction and mentoring between the lecturers as coaches and SMEs as partners. The study related to the development of a creative economy clinical model has not emerged. Therefore, based on our qualitative research, the establishment of a creative economy clinic within the tertiary environment has potential for those involved in the quadruple helix context. Although some cases and research results show that the problems faced by SMEs are solvable, the settlement is not holistic and continuous. For instance, issues related to a lack of capital and bookkeeping management can be overcome by assistance and training from the business incubators. However, the problem of marketing opportunities cannot be fully resolved due to the limitations of SMEs accessing digital technology. 
The lecturers, as partners unable to offer thorough technical assistance in fewer than one-two visits or provide remote and virtual consultation basis. Therefore, mentoring and training need to be conducted continuously since the business is a dynamic scheme.

The existence of higher education business incubators that are less than optimal in management and weak governance systems is also the reason for universities in Indonesia to initiate the development of a creative economy clinical model on campus. In the initial stages of developing the model, it is necessary to conduct a preliminary study identifying the needs of MSMEs for the follow-up mapping needed to create the intended business clinic model. The distribution of the indicators chosen to obtain a study of the needs of MSMEs as an initial stage of developing the clinical model consists of the profile of the business owner, business profile, and business performance. The results of identifying the needs of MSMEs are expected to provide a positive outcome for universities to actualize an efficient and effective creative economic clinic model.

\section{Author Contribution}

Andri Zainal and T. Citra Nisa Farza conceived of the presented idea as well as developed theory and literature review. Khairunnisa Harahap and Pasca Dwi Putra verified research and analytical methods and performed the statistical analysis. Andri Zainal encouraged T. Citra Nisa Farza and Pasca Dwi Putra to update contents following comments from the reviewers and supervised the findings of the relevant works, especially for those concerning to the Indonesian contexts. All authors discussed the results and contributed to the final manuscript.

\section{Acknowledgments}

We thank Universitas Negeri Medan (UNIMED) and Institute of Research and Community Service of UNIMED for providing funding and valuable insight that greatly contributed to the paper. We are also very grateful to have comments from reviewers of AJCE and proofreading outcome that significantly improved the manuscript. 


\section{References}

Afonso, O., Monteiro, S., \& Thompson, M. (2012). A Growth Model For The Quadruple Helix. Journal of Business Economics and Management, 13(5), 849-865. https://doi.org/10.3846/16111699.2011.626438

Agustina, T. S. (2011). Peran Inkubator Bisnis Perguruan Tinggi Dalam Meminimalkan Resiko Kegagalan Bagi Wirausha Baru Pada Tahap Awal (Start-Up). Majalah Ekonomi, XXI(1), 64-74.

http://journal.lib.unair.ac.id/index.php/ME/article/view/834/829

Alexander, U., \& Evgeniy, P. (2012). The Entrepreneurial University in Russia: from Idea to Reality. Procedia-Social and Behavioral Sciences, 52, 45-51.

https://doi.org/10.1016/j.sbspro.2012.09.440

Bacigalupo, M., Kampylis, P., Punie, Y., \& Van den Brande, G. (2016). EntreComp: The Entrepreneurship Competence Framework. Luxembourg: Publication Office of the European Union; EUR 27939 EN.

https://doi.org/10.2791/593884

Badan Ekonomi Kreatif. (2017). Laporan PDB Ekonomi Kreatif Tahun 2014-2016. Badan Ekonomi Kreatif Kerjasama Badan Pusat Statistik.

https://www.bekraf.go.id/downloadable/pdf_file/170475-data-statistik-dan-hasilsurvei-ekonomi-kreatif.pdf

Badan Ekonomi Kreatif. (2018, November 19). Laporan Opus 2019. Badan Ekonomi Kreatif Kerjasama Badan Pusat Statistik. Retrieved from: https://bekraf.go.id/pustaka/page/89-opus-creative-economy-outlook-2019indonesia-version

Bergmann, H., Geissler, M., Hundt, C., \& Grave, B. (2018). The climate for entrepreneurship at higher education institutions. Research Policy, 47(4), 700-716.

https://doi.org/10.1016/j.respol.2018.01.018

Boldureanu, G., Ionescu, A. M., Bercu, A. M., Bedrule-Grigoruţă, M. V., \& Boldureanu, D. (2020). Entrepreneurship education through successful entrepreneurial models in higher education institutions. Sustainability (Switzerland), 12(3), 1-33. 
Bomani, M., Fields, Z., \& Derera, E. (2019). The Role of Higher Education Institutions In The Development of SMES in Zimbabwe. International Journal of Business and Management Studies, 11(2), 1-15.

https://doi.org/10.1007/BF00162541

Campbell, C. (1989). Change Agents in the New Economy: Business Incubators and Economic Development. Economic Development Review, 7(2), 56-59.

https://search.proquest.com/openview/5f01225e3e32ae50bde1556231dec26f/1? pq-origsite $=$ gscholar \&cbl=38209

Chipangura, A., \& Kaseke, N. (2012). Growth Constraints of Small and Medium Enterprises (SMEs) at Glenview Furniture Complex (GFC) in Harare (Zimbabwe). International Journal of Marketing and Technology, 2(6), 40-83.

http://www.ijmra.us

D’Imperio, R. (2013). Growing the global economy through SMEs Contents. In Edinburgh Group, 1(1).

http://www.edinburgh-group.org/media/2776/edinburgh_group_research__growing_the_global_economy_through_smes.pdf

Darwish, S. Z. (2014). The Role of Universities in Developing Small and Medium Enterprises (SMEs): Future Challenges for Bahrain. International Business and Management, 8(2), 70-77.

\section{https://doi.org/10.3968/4776}

Delfmann, H., \& Koster, S. (2012). Knowledge Transfer between SMEs and Higher Education Institutions: Differences between Universities and Colleges of Higher Education in the Netherlands. Industry and Higher Education, 26(1), 31-42. https: / /doi.org/10.5367/ihe.2012.0079

Dessy, I. (2007). Strengthening Cluster Building in Developing Country alongside the Triple Helix: Challenge for Indonesian Clusters - A Case Study of the Java Region. In MPRA Paper (Issue 5831).

http://mpra.ub.uni-muenchen.de/5831/

Doyle, G. (2016). Creative Economy and Policy. European Journal of Communication, 31(1), 33-45. 
Efi, A. E. (2014). "The Role of Higher Institutions in Promoting Entrepreneurship and Small Business in Developing Nations: The Nigerian Experience", International Journal for Innovation Education and Research, 2(9), 15-22.

https://doi.org/10.31686/ijier.vol2.iss9.233

Eisler, R., \& Montuori, A. (2001). The Partnership Organization. OD Practitioner, 33, 1117.

https://www.researchgate.net/publication/259189006_The_Partnership_Organiza tion

Eniola, A. A., \& Ektebang, H. (2014). SME Firms Performance In Nigeria: Competitive advantage and its impact. International Journal of Research Studies in Management, $3(2), 75-86$.

\section{https://doi.org/10.5861/ijrsm.2014.854}

Etzkowitz, H. (2008). The Triple Helix: University-industry-government innovation in action. London: Routledge.

https://doi.org/10.1111/j.1435-5957.2011.00357

Fahmi, F. Z., McCann, P., \& Koster, S. (2015). Creative economy policy in developing countries: The case of Indonesia. Urban Studies, 54(6), 1-18.

https://doi.org/10.1177/0042098015620529

Famiola, M., \& Hartati, S. (2018). Entrepreneurship learning system in business incubators: An case study in Indonesia. International Journal of Engineering and Technology (UAE), 7(4), 57-62.

https://doi.org/10.14419/ijet.v7i4.28.22390

Fukuyama, M. (2018). Society 5.0: Aiming for a New Human-centered Society. Japan Spotlight, 1, 47-50.

http://www8.cao.go.jp/cstp/\%0Ahttp://search.ebscohost.com/login.aspx?direct=t rue $\& \mathrm{db}=\mathrm{bth} \& \mathrm{AN}=108487927 \&$ site $=$ ehost-live

Gasparin, M., \& Quinn, M. (2020). The INCITE model of policy development for the creative industries: the case of Vietnam. Journal of Asian Business and Economic Studies, 27(1). 
Gilson, L. L., \& Goldberg, C. B. (2015). Editors' Comment: So, What Is a Conceptual Paper? Group and Organization Management, 40(2), 127-130. https://doi.org/10.1177/1059601115576425

Gronroos, C. (1990). Service Management: A Management Focus for Service Competition. International Journal of Service Industry Management, 1(1), 6-14. https://doi.org/10.1108/09564239010139125

Hasbullah, R., Surahman, M., Yani, A., Almada, D. P., \& Faizaty, E. N. (2015). Peran Inkubator Bisnis Perguruan Tinggi dalam Peningkatan Kinerja Usaha UKM Pangan (Role of Universty Bussiness Incubators on the Improvement of Food SMEs Bussiness Performances). Jurnal Ilmu Pertanian Indonesia (JIPI), 20(1), 59-65.

https://journal.ipb.ac.id/index.php/JIPI

Herawati, A. R. (2011). Sistem Kemitraan Usaha Mikro Kecil Menengah (UMKM) - Usaha Besar Dengan Pemodelan System Archetype. Universitas Indonesia. Retrieved from: http://lib.ui.ac.id/detail.jsp?id=20306720\#parentHorizontalTab2

Hunjet, A., Kozina, G., \& Kurečić, P. (2015). The Role of Higher Education Institutions in the Development of Entrepreneurship Competences on the Study Programs other than Economics. Proceedings of the 9th Economic and Social Development Conference, $620-629$.

\section{https://www.bib.irb.hr/757492}

Ismulyati, S., \& Ginting, G. (2018). Entrepreneurship modeling in higher education institutions: An explanatory study. Review of Integrative Business and Economics Research, 7(3), 181-189.

https://sibresearch.org

Jaakkola, E. (2020). Designing conceptual articles: four approaches. AMS Review, 1-9. https://doi.org/10.1007/s13162-020-00161-0

Jaelani, A. (2019). Triple Helix Sebagai Model Bagi Inovasi Pendidikan Tinggi: Analisis Logika Kelembagaan Dalam Pengembangan Kewirausahaan Dan Ekonomi. Al-Amwal: Jurnal Ekonomi dan Perbankan Syari'ah, 11(1), 121-138. 
Jung, H., \& Mah, J. S. (2014). The Role of the Government in Science and Technology Education of Korea. Science, Technology and Society, 19(2), 199-227. https://doi.org/10.1177/0971721814529877

Kasim, R. S. R. (2011). Malaysian Higher Education Institutions: Shaping an Entrepreneurial Agenda. International Journal of Information and Education Technology, 1(2), 163-170.

https://doi.org/10.7763/ijiet.2011.v1.27

Kaymas, S. (2020). Is development possible without cultural policies? Rethinking creative industries and sustainable development in the case of Turkey. Creative Industries Journal, 13(1), 72-92.

https://doi.org/10.1080/17510694.2019.1652026

Khurana, A. (2017, August). How startup accelerators, incubators, and mentors are failing our entrepreneurs.

https://yourstory.com/2017/08/startup-accelerators-incubators-mentors-failingentrepreneurs

Kim, S. M., \& Sherraden, M. (2014). The impact of gender and social networks on microenterprise business performance. Journal of Sociology and Social Welfare, $41(3), 48-70$.

https://scholarworks.wmich.edu/jssw/vol41/iss3/4

Kontrimienè, V., \& Melnikas, B. (2017). Creative Industries: Development Processes Under Contemporary Conditions of Globalization. Business, Management and Education, 15(1), 109-126.

https://doi.org/10.3846/bme.2017.340

Krauss, S. E. (2005). Research Paradigms and Meaning Making : A Primer. The Qualitative Report, 10(4), 758-770.

https://doi.org/10.1176/appi.ajp.162.10.1985

Li, C., Ahmed, N., Qalati, S. A., Khan, A., \& Naz, S. (2020). Role of Business Incubators as a Tool for Entrepreneurship Development: The Mediating and Moderating Role of Business Start-Up and Government Regulations. Sustainability, 12(5), 1822. 
McAdam, M., Miller, K., \& McAdam, R. (2018). Understanding Quadruple Helix relationships of university technology commercialisation: a micro-level approach. Studies in Higher Education, 43(6), 1058-1073.

https://doi.org/10.1080/03075079.2016.1212328

McGregor, S. (2018). Argumentative essays: position, discussion, and think-piece papers. In McGregor, S. Understanding and evaluating research (pp. 469-495). Thousand Oaks, CA: SAGE Publications, Inc.

https://doi.org/10.4135/9781071802656

Mei, W., \& Symaco, L. (2020). University-wide entrepreneurship education in China's higher education institutions: issues and challenges. Studies in Higher Education, 117.

https://doi.org/10.1080/03075079.2020.1735330

Moore, I. (2014). Cultural and Creative Industries Concept - A Historical Perspective. Procedia - Social and Behavioral Sciences, 110, 738-746.

https://doi.org/10.1016/j.sbspro.2013.12.918

Munandar, A. (2016). the Strategy Development and Competitive Advantages of Micro Small Medium Entreprise Business Institution Toward Regional Development. Jurnal AdBispreneur, 1(2), 103-112.

https://doi.org/10.24198/adbispreneur.v1i2.10233

Nainggolan, R. (2016). Gender, Tingkat Pendidikan Dan Lama Usaha Sebagai Determinan Penghasilan UMKM Kota Surabaya. Kinerja, 20(1), 1-12.

https://doi.org/10.24002/kinerja.v20i1.693

Ndabeni, L. L. (2008). The contribution of business incubators and technology stations to small enterprise development in South Africa. Development Southern Africa, 25(3), 259-268.

https://doi.org/10.1080/03768350802212022

Nicolaides, A. (2011). Entrepreneurship- the role of Higher Education in South Africa. Educational Research, 2(4), 1043-1050.

https://www.researchgate.net/publication/228470234_Entrepreneurshipthe_role_of_Higher_Education_in_South_Africa 
Nugraha, A. E. P. (2018). Pengelolaan dan Strategi UMKM di Era Disrupsi Digital. Proceeding Seminar Nasional, 887-890.

http://prosiding.upgris.ac.id/index.php/SNKIII/SNK2018/paper/view/3097/3044

O’Malley, B. (2016). Universities Playing 'Key Role' in Growth of Start-Ups. https://www.universityworldnews.com/post.php?story=20160127162334861

Obaji, N. O., Onyemerela, C., \& Olugu, M. U. (2015). Entrepreneurship and Business Incubation Programme : the Sure Couple. International Journal of Science, Technology and Management, 4(1), 1627-1633.

https://pdfs.semanticscholar.org/7ad7/0298d590d16371ff58a9caa5fa5bc03b617 b.pdf

Ogutu, V. O., \& Kihonge, E. (2016). Impact of Business Incubators on Economic Growth and Entrepreneurship Development. International Journal of Science and Research (IJSR), 5(5), 231-241.

https://doi.org/10.21275/v5i5.nov163196

Pettersen, I. B., Aarstad, J., Høvig, Ø. S., \& Tobiassen, A. E. (2015). Business incubation and the network resources of start-ups. Journal of Innovation and Entrepreneurship, 5(7). https://doi.org/10.1186/s13731-016-0038-8

Piterou, A., \& Birch, C. (2014). The role of Higher Education Institutions in supporting innovation in SMEs: university-based incubators and student internships as knowledge transfer tools. InImpact: The Journal of Innovation Impact, 7(1), 72-79. http://nimbusvault.net/publications/koala/inimpact/papers/inkt14-010.pdf

Plechero, M. (2009). The Role of Local Universities in Improving Traditional SMEs Innovative Performances: The Veneto Region Case.

https://pdfs.semanticscholar.org/04ab/41750baf4f74a0189de8891b18575ff030fa .pdf?_ga=2.215628948.263377519.1595307714-645515529.1595307714

Pramudita, B. A. (2019, October 3). Pertumbuhan Startup di Indonesia melonjak 5 tahun terakhir.

https://www.wartaekonomi.co.id/read249740/pertumbuh-startup-in-Indonesiasoaring-5years-last 
Praswati, A. N. (2017). Perkembangan Model Helix Dalam Peningkatan Inovasi. Seminar Nasional Riset Manajemen \& Bisinis : Perkembangan Konsep Dan Riset E-Business Di Indonesia, 690-705.

\section{https://publikasiilmiah.ums.ac.id/handle/11617/9022}

Provenzano, V., Arnone, M., \& Seminara, M. R. (2016). Innovation in the Rural Areas and the Linkage with the Quintuple Helix Model. Procedia - Social and Behavioral Sciences, $223,442-447$.

https://doi.org/10.1016/j.sbspro.2016.05.269

Rofida, Y. A. (2018). Strategi Pelayanan pada Klinik (UMKM) Usaha Mikro, Kecil dan Menengah Dinas Koperasi Provinsi Jawa Timur. Universitas Negeri Surabaya: Surabaya.

https://doi.org/10.1017/CB09781107415324.004

Saad, M., \& Zawdie, G. (2011). Theory and practice of the Triple Helix model in developing countries: Issues and challenges. Taylor \& Francis.

https://doi.org/10.4324/9780203838211

Salem, M. I. (2014). The Role Of Business Incubators In The Economic Development Of Saudi Arabia. International Business \& Economics Research Journal (IBER), 13(4), 853. https://doi.org/10.19030/iber.v13i4.8694

Shafi, M., Sarker, M. N. I., \& Junrong, L. (2019). Social network of small creative firms and its effects on innovation in developing countries. SAGE Open, 9(4), https://doi.org/10.1177/2158244019898248

Sofhani, T. F., \& Nurrahma, V. (2017). Pengembangan Wilayah berbasis Quadruple Helix: Analisis Jaringan Antar Aktor dalam Pengembangan Industri Kreatif Cimahi. Prosiding Seminar Nasional Perencanaan Pembangunan Inklusif Desa Kota, 17-26. http://digilib.mercubuana.ac.id/manager/t!@file_artikel_abstrak/Isi_Artikel_17874 2985743.pdf

Stake, R. E. (1995). The art of case study research. Sage. 
Suwandi, S. (2007). Pengembangan Model Inkubator Bisnis Perguruan Tinggi. Jurnal Penelitian Humaniora, 12(2), 65-86. https://journal.uny.ac.id/index.php/humaniora/article/view/5012/4314

UNDP (United Nations Development Programme). (2013). Creative Economy Report 2013 Special Edition: Widening Local Development Pathways, PNUD. http://www.unesco.org/culture/pdf/creative-economy-report-2013.pdf

Setyanti, S. W. L. H. (2017). The Quadruple Helix Model: Enhancing Innovative Performance Of Indonesian Creative Industry. International Journal of Scientific \& Technology Research, 6(11), 90-94.

http://www.ijstr.org/final-print/nov2017/The-Quadruple-Helix-Model-EnhancingInnovative-Performance-Of-Indonesian-Creative-Industry.pdf

Wiagustini, N. L. P., Mustanda, I. K., Meydianawathi, L. G., \& Abundanti, N. (2017). Potensi Pengembangan Investasi Berbasis Ekonomi Kreatif di Kota Denpasar. Jurnal Ekonomi Kuantitatif Terapan, 10(2), 155-173.

https://doi.org/10.24843/JEKT.2017.v10.102.p06.

Widiastuti, L., \& Tjokropandojo, D. S. (2016). Jaringan Sosial Kota Pekalongan sebagai Modal Dukungan Perwujudan Kota Kreatif. Jurnal Perencanaan Wilayah Dan Kota, 1(1), 1-15.

https://digilib.itb.ac.id/index.php/gdl/download/149794

Wilson, T. (2012). A Review of Business-University Collaboration (Issue February 2012). https://assets.publishing.service.gov.uk/government/uploads/system/uploads/att achment_data/file/32383/12-610-wilson-review-business-universitycollaboration.pdf

Yoon, H., \& Lee, J. J. (2013). Entrepreneurship education and research commercialization of engineering-oriented universities: an assessment and monitoring of recent development in Korea. International Journal of Engineering Education, 29(5), 10681079.

https://www.researchgate.net/publication/276912651_Entrepreneurship_Educati on_and_Research_Commercialization_of_Engineering-

Oriented_Universities_An_Assessment_and_Monitoring_of_Recent_Development_in_ Korea 